\title{
TEKNOLOGI SILASE KOMPLIT SEBAGAI PAKAN KAMBING PADA KELOMPOK TERNAK REZEKI DI DESA SEGARAN KECAMATAN PAGEDANGAN KABUPATEN MALANG
}

\author{
D.R.A Daning ${ }^{1}$, K.B. Utami ${ }^{2}$, dan Riyanto ${ }^{3}$
}

\begin{abstract}
ABSTRAK
Kelompok tani Rezeki berada di Desa Segaran wilayah Kecamatan Pagedangan dengan jarak lokasi dari pusat pemerintahan Kabupaten Malang kurang lebih sekiatr $20 \mathrm{~km}$ (Malang bagian selatan) yang memelihara ternak kambing dengan sistem semi intensi, sehingga ternak tidak mendapat pakan sesuai dengan kebutuhan. Kegiatan pembinaan desa mitra sekaligus pembinaan peningkatan regenerasi muda pertanian dari program Politeknik Pembangunan Pertanian Malang menyediakan dukungan berupa ternak kambing sebanyak 4 ekor betina dan satu kambing untuk setiap kelompok ternak. Ternak kambing sangat membutuhkan pakan dengan jumlah dan mutu yang berkualitas, sehingga pucuk tebu belum dimanfaatkan secara baik oleh peternak dan hanya dibakar. Pengabdian ini dilaksanakan selama 12 bulan dengan metode yang digunakan adalah penyuluhan, demplot (Pengawetan pakan dan Pemberian pakan). Peningkatan pengetahuan peternakan tentang pemeliharaan ternak kambing dengan sistem pemelihraan semi intensif, pemanfaatan pucuk tebu sebagai pakan ternak dan pengawetan pakan dengan cara pembuatan silase komplit, sehingga mampu memberi kontinyuitas pakan sepanjang musim dan tidak pencemaran lingkungan dengan dibakar. Kegiatan dilanjutkan dengan memberikan pakan silase komplit yang sudah jadi dengan memanfaatkan limbah pertanian dan sumber legume (pakan lokal) yang terdapat disekitar usaha peternakannya serta mengadopsi informasi teknologi penyediaan pakan untuk ternak kambing.
\end{abstract}

Kata Kunci: Silase komplit, penyuluhan, pelatihan, dan pemberdayaan.

\section{ABSTRACT}

Rezeki farmer group are located in Segaran, Pagedangan subdistrict with a distance of about $20 \mathrm{~km}$ from the central of Malang which maintains goats with semi-intention system, so that livestock do not get feed based on their requirements. The community service activities are collaborated with young entrepreneurship program from Agricultural of Development Polytechnic, Malang which given 5 of female goats and 1 of male goats for each farmer groups. Because of that reasons, we have program to give consultant and training about the utilization of sugarcane leaf, and others grass in around farmer living. This service was carried out for 12 months with the methods used were counseling, demonstration plots (Feed preservation (silage) and feeding). Increased farmer knowledge about raising goats with a semiintensive maintenance system which is the utilization of sugar cane leaf as animal feed and preservation of feed by means of complete silage production. The purpose of this service is to train farmer due to providing the continuity of feed throughout the season and not to pollute the environment by burning that is silage complete technology by utilizing agricultural waste and the source of legumes (local feed) found around its livestock business and adopting information on the technology of providing feed for goats

Keywords: silage complete, counseling, training, and empowerment.

\section{PENDAHULUAN}

Pakan merupakan faktor yang mempengaruhi dari produktivitas ternak, banyak peternak memiliki kendala saat musim kemarau dalam penyediaan bahan pakan ternak. Ada 2 masalah utama yang menyebabkan pakan ternak khususnya pakan ternak ruminansia yang diberikan tidak memenuhi kecukupan jumlah dan asupan nutrient. Masalah pertama adalah bahan pakan pada umumnya berasal dari limbah pertanian yang rendah kadar protein kasarnya dan tinggi serat

${ }^{1}$ Politeknik Pembangunan Pertanian Malang, daningstpp@gmail.com ).

1,2,dan $3^{2}$ Dosen Program Studi Penyuluhan Peternakan dan Kesejahteraan Hewan. pengajar 
kasarnya. Tingginya kadar serat ini yang umumnya didominasi komponen lignoselulosa yang sulit dicerna (McDonald et al., 2002). Masalah lainnya adalah ketersedian pakan yang tidak kontinyu. Ini dikarenakan langkanya bahan pakan terutama di musim kemarau. Untuk mengatasi masalah tersebut berbagai terobosan telah dilakukan. Untuk meningkatkan nilai gizi dari pakan ternak yang umum dilakukan adalah dengan membuat menjadi hijauan kering (hay), penambahan urea (amoniasi) dan awetan hijauan (silase).

Pucuk tebu merupakan limbah tanaman yang sangat potensial sebagai pakan ternak karena jumlahnya tersedia banyak dan tidak bersaing dengan kebutuhan manusia. Tanaman tebu menghasilkan limbah pucuk tebu sebesar 30\%. Kandungan zat makanan pucuk tebu adalah bahan kering 39,9\%, protein kasar 7,4\%, serat kasar 42,30\%, lemak kasar 2,90\%, BETN 40,00\%, dan abu 7,40\% (Murni, dkk. 2008; Silitonga, 1985). Menurut Leng (1995) bahwa dalam satu hektar kebun tebu akan diperoleh 180 ton biomassa / tahun yang terdiri atas 38 ton pucuk tebu dan 72 ton ampas tebu yang mampu menyediakan pakan ternak sapi sebanyak 17 ekor dengan bobot $250-450 \mathrm{~kg}$, Agar pemanfaatan pucuk tebu lebih optimal dalam meningkatkan dan mempertahankan daya gunanya maka di lakukan teknologi pengolahan dengan pembuatan silase.

Silase merupakan hijauan yang diawetkan dengan cara fermentasi dalam kondisi kadar air yang tinggi (40-80\%). Keunggulan pakan yang dibuat silase adalah pakan tahan lama, tidak memerlukan proses pengeringan, meminimalkan kerusakan zat makanan/gizi akibat pemanasan serta mengandung asam-asam organik yang berfungsi menjaga keseimbangan populasi mikroorganisme pada rumen. Konsep teknologi silase yang dikembangkan selama ini masih bersifat silase tunggal (single silage) dengan menggunakan satu jenis hijauan, beberapa penelitian tentang pengembangan teknologi silase sudah banyak diterapkan mulai dari penggunaan berbagai mikroorganisme dan silase komplit yaitu menggunakan silase dengan berbagai campuran hijauan baik rumput dan legume. Menurut penelitian Chalisty (2017) penggunaan silase total campuran hijauan yang terdiri dari jerami padi $(48,5 \%)$, jerami jagung $(36,5 \%)$, rumput raja $(5 \%)$, Gamal $(5 \%)$, dan jerami kacang tanah $(5 \%)$ dengan ditambahkan beberapa mikroorganisme asam laktat dihasilkan kualitas Uji kualitas fisik menunjukkan warna hijau kekuningan, bau asam, tekstur padat, dan keberadaan jamur sedikit/tidak ada jamur. Penambahan molases atau sumber karbohidrat mudah larut merupakan suatu keharusan untuk menghasilkan silase total campuran hijauan yang baik, ditunjukkan dengan $\mathrm{pH}$ sebesar 3,60, kandungan asam laktat sebesar 4,28\% BK, kandungan amonia sebesar 0,43\% BK. Berbeda dengan silase tunggal, silase komplit memiliki beberapa keunggulan sebagai berikut: 1) lebih mudah dalam pembuatannya, 2) kandungan gizi yang dihasilkan lebih tinggi dapat memenuhi 70-90 persen kebutuhan gizi ternak kambing 3) Memiliki sifat organoleptis (bau harum, asam) sehingga lebih disukai ternak (palatable).

Daerah malang selatan kondisi lahan yang kering juga menyebabkan terbatasnya ketersediaan hiajuan pakan ternak. Rumput lapangan yang merupakan sumber hijauan pakan ternak paling utama saat musim hujan, juga menjadi langka saat musim kemarau. Sumber hijauan pakan ternak yang paling utama pada saat musim kemarau adalah daun tebu dan ketela pohon (ubi kayu) yang tersedia melimpah pada saat musim panas. Desa Segaran, Kecamatan Pagedangan, Kabupaten Malang merupakan desa di daerah Malang selatan, yang terdiri daerah pegununagan, dan banyak tanah tegalan serta merupakan sentra petani tebu. Saat musim panentebu banyak sekali pucuk daun tebu yang terbuang dan dibakar oleh warga dikarenakan belum diketahui adanyak teknik pengawetan hijauan (silase). Kelompok Ternak yaitu Rezeki Anggota kelompok 20 Peternak dengan areal tegalan seluas 15 ha Pelatihan ini kerjasama dengan Politeknik Pembangunan Pertanian Malang melalui kegiatan Pengabdian Masyarakat Desa Mitra dengan tujuan meningkatkan pengetahuan dan keterampilan masyarakat dalam berternak kambing khususnya dalam penyediaan pakan yang berbasis lokal yang ada disekitar usaha peternakan kambing dilakukan. 


\section{Metode Pelaksanaan}

Kegiatan yang dilakukan dalam program pengabdian masyarakat ini meliputi kegiatan penyuluhan dan pelatihan pemanfaatan pakan local untuk kambing bagi masyrakat mitra di Desa Segaran, Kecamatan Pagedangan, Kabupaten Malang, Jawa Timur. Sebanyak 20 peserta mitra mengikuti kegiatan ini dengan narasumber 3 orang.

Kegiatan penyuluhan bertujuan memperkaya pengetahuan masyarakat peternak kambing dalam pemeliharaan kambing secara umum dan khususnya berbagai jenis pakan dan cara pemberiannya pakan untuk kambing. Sistem pemaparan materi dan dilanjutkan dengan diskusi diterapkan dalam kegiatan ini. Masyarakat peserta dibekali dengan informasi tertulis sebagai pegangan untuk mengikuti penyuluhan dan untuk memberikan kesempatan merespon atas materi penyuluhan sehingga ada timbal balik dalam diskusi yang dilakukan. Masyarakat dirangsang untuk menyampaikan informasi ynag diketahuinya tentang jenis tanaman yang ada dan dikenal dalam kehidupannya sehari-hari yang berpotensi digunakan sebagai pakan kambing.

Kegiatan pelatihan pemanfaatan pakan local untuk kambing dilakukan setelah kegiatan penyuluhan. Materi pelatihan berupa bahan pakan hijauan yang ada disekitar terdiri dari pucuk tebu, rumput raja, tebon tebu, gamal, daun nangka, dan daun ketela. Jagung giling, dedak padi, dan pollard dibuat sebagai campuran ransum yang dapat diperoleh dengan mudah dan pemanfaatannya dalam ransum tidak dalam jumlah yang besar.

Prinsip pembuatan pakan komplit dalam bentuk silase ini seperti proses fermentasi pada umumnya. Bahan-bahan yang digunakan terdiri dari 3 kelompok bahan yakni kelompok rumput, legume, dan limbah pertanian. Bahan pakan hijauan disini berupa pucuk tebu, tebon tebu, gamal, daun nangka, dan daun ketela. Jagung giling, dedak padi, dan pollard.

Peralatan yang disiapkan dalam pelatihan antara lain tong, baskom, timbangan, dan terpal. Semua bahan hijauan dicacah sepanjang 3-5 cm yang dipanen sehari sebelum pembuatan silase komplit, kemudian semua bahan dicampur rata dan dipadatkan secara rapat di tong penyimpanan, kemudian dipanen setelah 21 hari. Susunan silase komplit dengan kadar protein 16\% adalah sebagai berikut:
1. Pucuk tebu : $45 \%$
2. Tebon jagung : $: 30 \%$
3. Gamal : $15 \%$
4. Daun nangka $: 5 \%$
5. Daun ketela: $5 \%$
6. Pollard : $3 \%(\mathrm{w} / \mathrm{v})$

\section{Hasil dan Pembahasan}

Kegiatan penyuluhan diikuti dengan serius oleh masyarakat peserta serta adanya upaya untuk memahami apa yang disampaiakan. Masyarakat sangat berantusias dalam praktek demonstrasi cara pembuatan silase komplit yaitu kegiatan dimulai dengan proses pencacahan hijauan menggunakan arit/golok, dilanjutkan dengan pencampuran bahan additive dan pemanpatan hijauan pada silo sehingga anaerob. Proses pembuatan silase komplit tersaji pada Gambar 1. Proses pendampingan desa mitra dilanjutkan hingga pengimplementasian silase pada ternak kambing.

Pemeliharaan ternak kambing dengan mengandalkan potensi pakan lokal yang ada disekitar kehidupannya merupakan upaya pemberdayaan dalam rangka meningkatkan kesajahteraan dengan memanfaatkan semua sumberdaya yang dimiliki dan yang ada disekitarnya. Hal ini seperti dikemukakan Setiana (2005) bahwa, kegiatan pemberdayaan masyarakat adalah upaya mengaktualisasikan potensi yang sudah dimiliki sendiri oleh masyarakat. Masyarakat mitra 


\section{D.R.A Daning, K.B. Utami, dan Riyanto}

diperkenalkan pada berbagai tanaman local yang berpotensi sebagai pakan ternak kambing tersaji dalam Gambar 2.
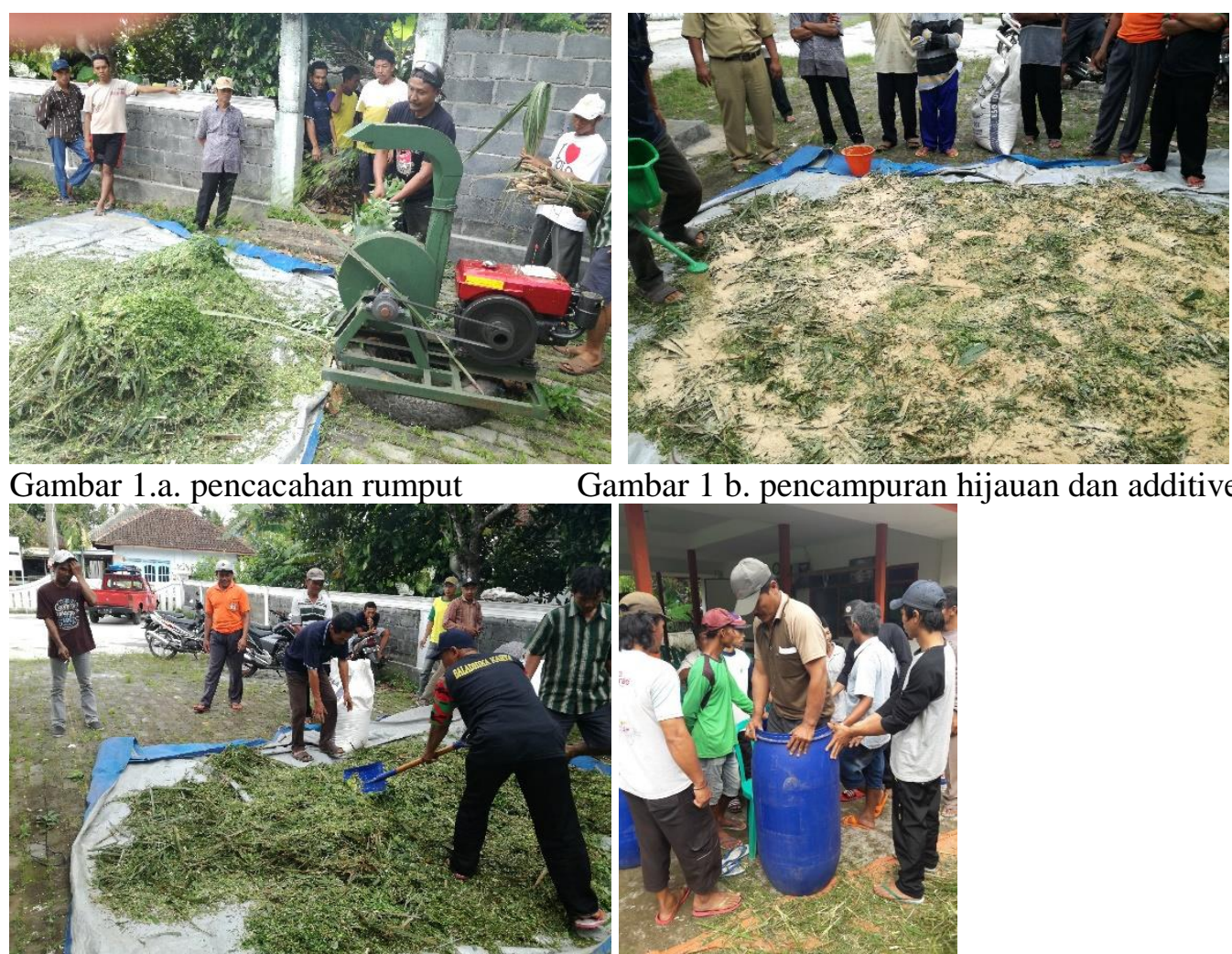

Gambar 1 b. pencampuran hijauan dan additive

Gambar 2.c. Pemampatan hijauan pada silo (tong)
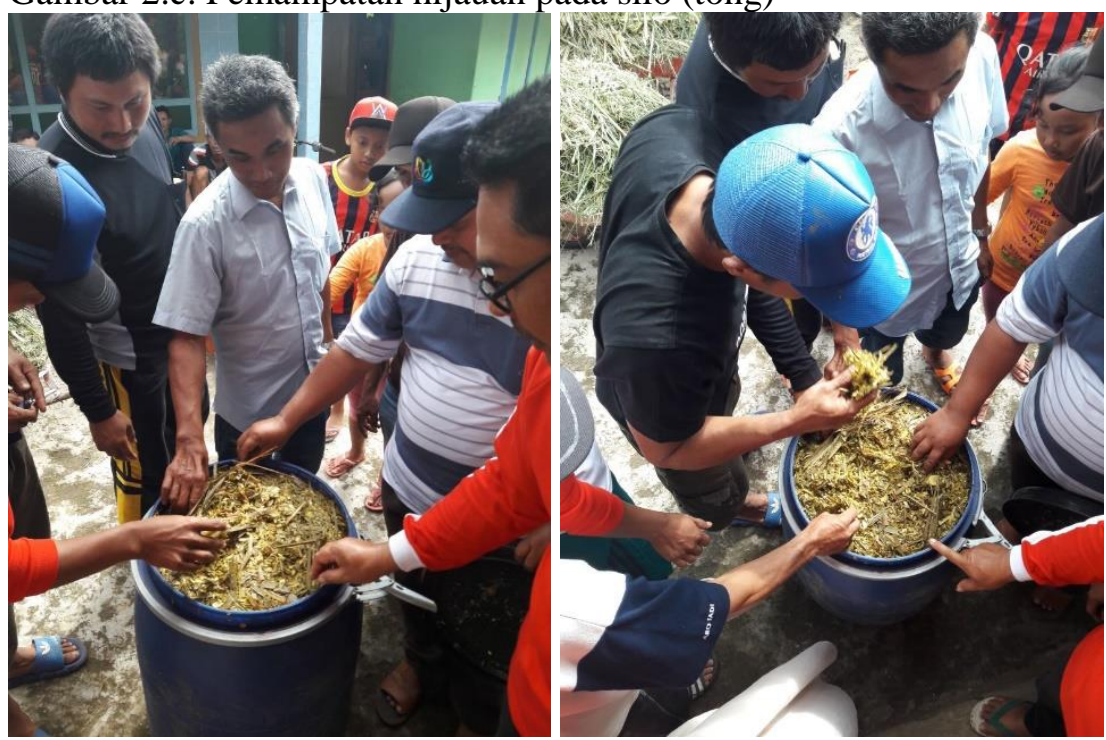

Gambar 2 d. pemanenan silase setelah 21 hari.

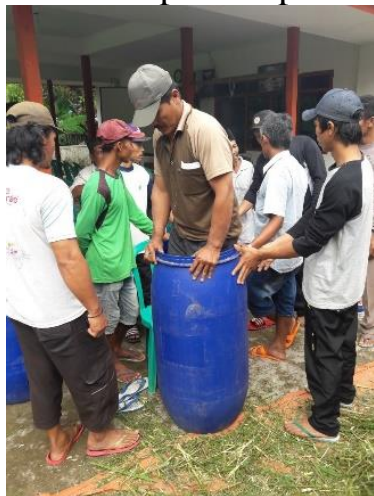

Hasil silase komplit yang sudah dibuat oleh warga dengan periode fermentasi selama 21 hari dihasilkan kualitas silase bau asam segar warna hijau kecoklatan, tanpa adanya jamur kontaminan yang tumbuh tersaji dalam gambar 2.d. Menurut Hidayat, 2014 menjelaskan bahwa kualitas silase rumput yang difermentasi menggunakan tambahan karbohidrat (molases dan onggok) dihasilkan bau asam segar, warna hamper sama aslinya, tekstur lembut, menurut Siregar (1996) menyatakan bahwa, secara umum silase yang baik mempunyai ciri-ciri yaitu tekstur masih jelas seperti alamnya. Hasil penelitian Syarifuddin (2006) melaporkan bahwa tekstur silase pada berbagai umur pemotongan (20 hari hingga 80 hari) menunjukkan tekstur yang remah. 
Teknologi silase komplit ini perlu adanya identifikasi potensi jenis-jenis tanaman pakan apa saja yang dapat digunakan sebagai pakan ternak kambing. Identifikasi genus/spesies hijauan pakan semakin penting dilakukan mengingat semakin pentingnya arti hijauan pakan bagi kebutuhan ternak. Identifikasi hijauan pakan khususnya rumput dapat dilakukan berdasarkan pada tanda-tanda atau karakteristik vegetative. Kebiasaan peternak di Indonesia mencari sumber pakan disekitar pematang sawah dan tegalan rata-rata jenis legume yang digunakan adalah gamal dan kaliandra, hal ini sejalan dengan penelitian (Daning dan FoEkh, 2018) bahwa diperoleh data produksi tanaman kaliandra dan gamal tidak berbeda secara signifikan dengan total produksi daun $0,62 \mathrm{~kg} / 56$ hari dan $0,50 \mathrm{~kg} / 56$ hari secara bertururt-turut dan dihasilkan kualitas nutrisi dan kecernaan yang hampir sama.

Berdasarkan hasil penelitian Susanti dan Eko (2016) bahwa daun tanaman yang banyak digunakan oleh peternak responden di 5 (lima) lokasi penelitian dengan ketinggian yang berbeda adalah daun Sengon (Paraserianthes falcataria), Gamal (Gliricidia sepium), Nangka (Artocarpus heterophyllus), Lamtoro (Leucaena leucocephala) dan daun Kaliandra (Calliandra calothyrsus). Daun Sengon paling banyak digunakan di Desa Klampok Kecamatan Singosari (88,3\%). Proporsi penggunaan daun Kaliandra berkisar 32- 98\% sedangkan daun Gamal 58-98\%, keduanya paling banyak digunakan di Desa Argoyuwono Kecamatan Ampelgading. Daun Nangka paling banyak digunakan di Kecamatan Wajak (90,3\%) sedangkan daun Lamtoro 100\% digunakan oleh seluruh responden di Desa Sumberdem Kecamatan Wonosari.

Keberadaan tanaman-tanaman tersebut telah dikenal masyarakat, baik yang ada di pekarangan rumah, kebun, lading maupun yang ada dihutan namun belum dimanfaatkan dengan baik sebagai pakan kambing. Tanaman-tanaman tersebut memiliki kandungan nutrisi yang baik untuk dimanfaatkan sebagai pakan. Dalam penjelasan kepada mitra masyarakat peternak, mereka menjadi mengetahui, mengerti dan memahami bahwa pakan untuk ternak kambing dapat diperoleh disekitar usaha pertanian yang mereka lakukan sehari-hari. Melalui pengetahuan dan pemahaman yang dimiliki, masyarakat diharapkan menjadi mandiri dan meningkatkan kemampuannya dalam pemeliharaan ternak kambing dan memanfaatkan segala sumberdaya yang dimiliki untuk meningkatkan kesejahteraanya. 


\section{D.R.A Daning, K.B. Utami, dan Riyanto}

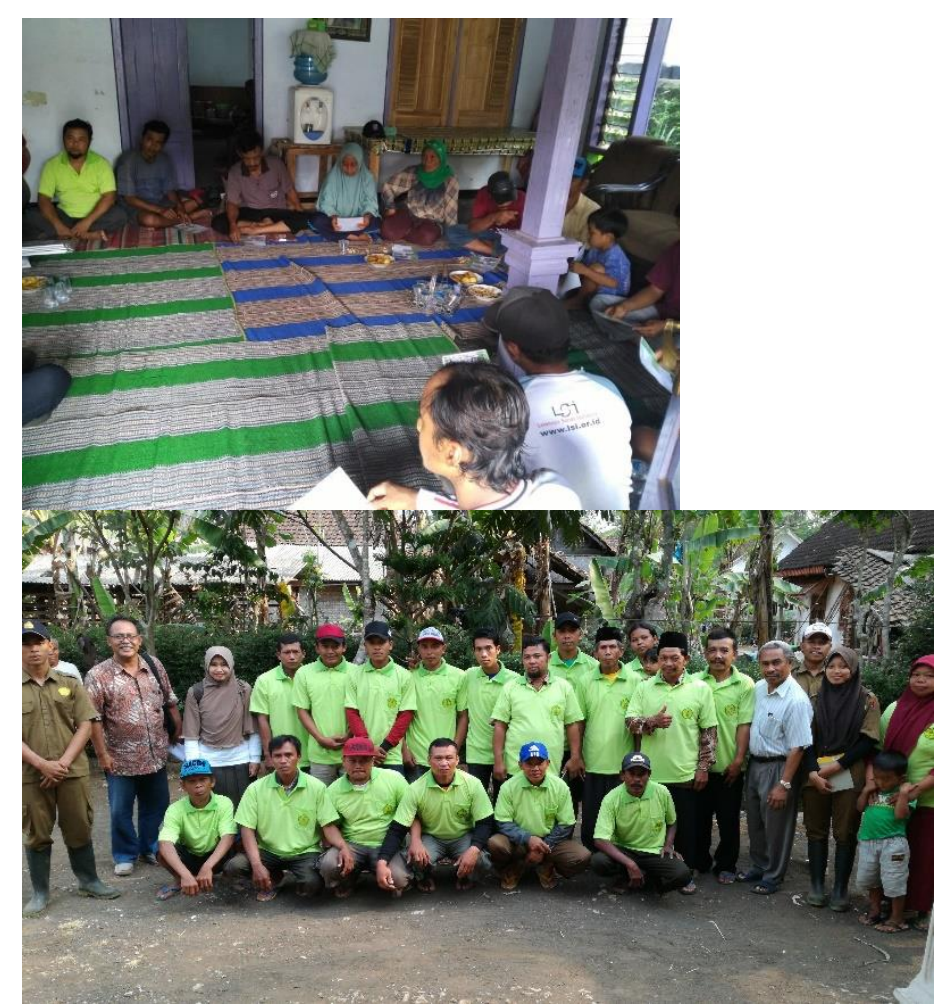

Gambar 3. Kegiatan dan peserta penyuluhan di kelompok ternak

Kegiatan pelatihan bertujuan memberikan nuansa aplikasi terhadap teknologi penyediaan pakan yang bermanfaat bagi masyarakat. Penyediaan pakan hijauan untuk ternak kambing dan ternak ruminansia lainnya selalu menjadi masalah utama dimusim kemarau dimana hijauan jenis rumput dan leguminosa sulit di dapat (Kushartono dan Iriani, 2004). Leguminosa sebagai pakan ternak mempunyai susunan zat makanan yang sangat baik, selain itu daunnya sangat disukai ternak kambing. Kambing mempunyai kebiasaan makan secara browsing karena lidahnya cekatan, sehingga juga dapat mengkonsumsi rumput-rumputan yang sangat pendek dan daun pohon atau semak-semak (to browse foliage) yang biasanya tidak dikonsumsi oleh ternak rumina nsia lain. Kebiasaan makan ternak kambing yang serba ingin mengetahui rasa makanan yang baru memungkinkan kambing menyukai banyak macam pakan, terutama pakan dengan kandungan serat tinggi. Kambing dapat memanfaatkan nutrisi yang terkandung dalam pakan jauh lebih baik daripada kebanyakan ternak ruminansia lain.

Hasil penyuluhan dan pelatihan dalam kegiatan program masyarakat ini diharapkan masyarakat termotivasi dan mengadopsi informasi dan menerapkannya dalam usaha peternakan kambing yang dilakukan. Teknnologi pembuatan silase komplit dengan berbagai sumber hijauan lokal daerah usaha peternakan yang mampu memenuhi kebutuhan nutrisi kambing. Dahlanuddin, et al (2002) menyampaikan hasil penelitiannya bahwa pemberian daun turi, gamal dan lamtoro (masing-masing $1 / 3$ bagian) pada akhir kebuntingan dan awal laktasi dapat mempercepat pertumbuhan anak. Kambing yang diberi daun turi sebagai pakan tunggal mampu meningkatkan berat badan rata-rata $86 \mathrm{~g} /$ hari. Hasil penelitian berikutnya menunjukkan bahwa pertambahan berat badan kambing yang diberi 50\% turi dan 50\% lamtoro mencapai $106 \mathrm{~g} / \mathrm{hari}$.

Hasil evaluasi kegiatan penyuluhan PKM telah dilakukan setelah 12 bulan dari kegiatan pelatihan. Rata-rata peternak sebanyak $75 \%$ sudah membuat teknologi silase komplit dengan pucuk tebu sebagai bahan utamanya dan sebagai ransum utama untuk memenuhi kebutuhan nutrisi ternak kambing. Teknologi ini akan memebrikan solusi untuk kecukupan gizi ternak kambing tidak hanya mengandalkan pakan tunggal. Penggunaan legume sebagai pakan tunggal pada ternak ruminansia, 
perlu adanya suatu penelitian, mengingat ada beberapa kendala penggunaan legume sebagai pakan ternak. Kendala penggunaan Kaliandra sebagai pakan tunggal adalah ketersediaan nutrient menjadi rendah karena Kaliandra mengandung tannin yang dapat melindungi protein dari proses perombakan oleh mikroba rumen dan proses enzimatis dalam usus, sehingga dapat menurunkan pemanfaatan nutrien oleh ternak. Tangendjaja et al. (1992) melaporkan bahwa kandungan tanin dalam Kaliandra sebesar 1,5 hingga 11,3 persendan memiliki daya cerna bahan keringsecara in vitro berkisar antara 35 hingga 53 persen.

\section{Kesimpulan dan Saran}

\section{Kesimpulan}

Masyarakat mitra peserta kegiatan PKM mendapat pengayaan dan ketrampilan penyediaan pakan bagi ternak kambing yang dipelihara dengan mengandalkan pakan lokal yang terdapat disekitar usaha peternakannya serta dapat mengadopsi informasi teknologi penyediaan pakan untuk ternak kambing yang bernutrisi dengan teknologi silase komplit. Selama periode evaluasi kegiatan setelah 12 bulan penyuluhan $75 \%$ peternak menerapkan teknologi silase.

\section{Saran}

Kegiatan PKM perlu adanya pendampingan berkelanjutan dalam perhitungan kapasitas produksi silase untuk memenuhi kebutuhan ternak kambing dalam satu tahun.

\section{Ucapan Terima Kasih}

Kami sebagai tim pengabdian mengucapkan terima kasih kepada Kementrian Pertanian melalui dana DIPA Polbangtan Malang atas pendanaan untuk Program Kemitraan Masyarakat (PKM) tahun anggaran 2018.

\section{Daftar Pustaka}

McDonald, P., Edwards, R. A., Greenhalg, J. F. D. and Morgan, C. A. 2002. Animal nutrition. 6th Ed. Ashford Color Pr., Gosport.

Murni, R., Suparjo, Akmal, B.L. Ginting. 2008. Buku Ajar Teknologi Pemanfaatan Limbah untuk Pakan. Laboraturium Makanan Ternak Fakultas Peternakan Universitas Jambi.

Chalisty, VD., R.U. Utomo, and Z. Bachrudin. 2017. The effect of molasses, Lactobacillus plantarum, Trichoderma virideae, and its mixtures additionon the quality of total mixed forage silage. Buletin Peternakan Vol. 41 (4): 431-438, November 2017 ISSN-0126-4400 E-ISSN-2407-876X Bulletin of Animal Science, DOI: 10.21059/buletinpeternak.v41i4.17337.

Siregar, M.E. 1996. Pengawetan Pakan Ternak. Penebar Swadaya. Jakarta.

Setiana, L. 2005. Teknik Penyuluhan dan Pemberdayaan Masyarakat. Ghalia Indonesia. Bogor.

Syarifuddin, N.A. 2006. Nilai gizi rumput gajah sebelum dan setelah ensilase pada berbagai umur pemotongan. Fakultas Peternakan Universitas Lambung Mangkurat Banjarbaru. Banjarmasin.

Susansti, S dan E. Marhaeniyanto. 2016. Proporsi penggunaan berbagai jenis daun tanaman untuk pakan ternak kambing pada lokasi dan ketinggian berbeda di wilayah Malang Raya. Jurnal Ilmu-Ilmu Peternakan 26 (3): 42 - 52, ISSN : 0852-3681, E-ISSN : 2443-0765, Fakultas Peternakan UB, http://jiip.ub.ac.id/ 
Daning, D.R.A dan B. FoEkh. 2018. Evaluasi Produksi dan Kualitas Nutrisi pada Bagian Daun dan Kulit Kayu Calliandra callotirsus dan Gliricidia sepium. Sains Peternakan Vol. 16 (1), Maret 2018: 7-11 www.jurnal.uns.ac.id/Sains-Peternakan. DOI: http://dx.doi.org/10.20961/sainspet.16.1.7-11 pISSN 1693-8828 eISSN 2548-9321

Dahlanuddin 2001: Forages commonly available to goats under farm conditions on Lombok Island, Indonesia. Livestock Research for Rural Development. Volume 13, Article \#10. Retrieved April 25, 2018, from http://www.lrrd.org/lrrd13/1/dahl131.htm

Kushartono, B., dan Iriani, N. 2004. Inventarisasi Keanekaragaman Pakan Hijauan Guna Mendukung Sumber Pakan Ruminansia. Prosiding Temu Teknis Nasional Tenaga Fungsional Pertanian 2004. Pusat Penelitian dan Pengembangan Peternakan, Badan Litbang Pertanian, Kementerian Pertanian. Hal. 66-71.

Tangendjaja, B., E. Wina, B. Palmer. dan T. Ibrahim. 1992. Kaliandra dan pemanfaatannya. ACIAR dan Balitnak 